\title{
SCIENTIFIC REP RTS \\ OPEN \\ Author Correction: Identification of urine protein biomarkers with the potential for early detection of lung cancer
}

Published online: 28 September 2018

\begin{abstract}
Hongjuan Zhang ${ }^{1,2}$, Jing $\mathrm{Cao}^{3}$, Lin $\mathrm{Li}^{2}$, Yanbin $\mathrm{Liu}^{2}$, Hong $\mathrm{Zhao}^{2}$, Nan $\mathrm{Li}^{3}$, Bo $\mathrm{Li}^{3}$, Aiqun Zhang ${ }^{4}$, Huanwei Huang ${ }^{2}$, She Chen ${ }^{2}$, Mengqiu Dong ${ }^{2}$, LeiYu ${ }^{5}$, Jian Zhang ${ }^{3}$ \& Liang Chen ${ }^{2,6}$
\end{abstract}

Correction to: Scientific Reports https://doi.org/10.1038/srep11805, published online 02 July 2015

The Acknowledgements section in this Article was omitted. The Acknowledgements section should read:

“This work was funded by NSFC (81472606) to L.C."

(c) (i) Open Access This article is licensed under a Creative Commons Attribution 4.0 International License, which permits use, sharing, adaptation, distribution and reproduction in any medium or format, as long as you give appropriate credit to the original author(s) and the source, provide a link to the Creative Commons license, and indicate if changes were made. The images or other third party material in this article are included in the article's Creative Commons license, unless indicated otherwise in a credit line to the material. If material is not included in the article's Creative Commons license and your intended use is not permitted by statutory regulation or exceeds the permitted use, you will need to obtain permission directly from the copyright holder. To view a copy of this license, visit http://creativecommons.org/licenses/by/4.0/.

(c) The Author(s) 2018
${ }^{1}$ School of Life Science, Tsinghua University, Beijing, 100084, China. ${ }^{2}$ National Institute of Biological Sciences, Beijing, 102206, China. ${ }^{3}$ Xijing Hospital, Xi'an, 510060, China. ${ }^{4}$ General Hospital of the People's Liberation Army, Beijing, 100853, China. ${ }^{5}$ Beijing Tongren Hospital, Capital Medical University, Beijing, 100730, China. ${ }^{6}$ National Institute of Biological Sciences, Collaborative Innovation Center for Cancer Medicine, Beijing, 102206, China. Hongjuan Zhang, Jing Cao, Lin Li and Yanbin Liu contributed equally. Correspondence and requests for materials should be addressed to J.Z. (email: zhangjian197011@yahoo.com) or L.C. (email: chenliang@nibs.ac.cn) 